\title{
APPLICATION OF LASER ADDITIVE MANUFACTURING TO PRODUCE DIES FOR ALUMINIUM HIGH PRESSURE DIE-CASTING ${ }^{\#}$
}

\author{
M.F.V.T. Pereira ${ }^{1 *}$, M. Williams ${ }^{2} \&$ W. B. du Preez ${ }^{3}$ \\ Metals and Metals Processes \\ CSIR Materials Science \& Manufacturing, South Africa \\ 1 mpereira@csir.co.za, ${ }^{2}$ mwilliam@csir.co.za, ${ }^{3}$ wdupreez@csir.co.za
}

\begin{abstract}
A number of laser additive manufacturing (LAM) technologies can produce fully-dense metal components that potentially offer opportunities to apply the technology in die or mould making (known as rapid tooling). From these LAM technologies, three were selected for evaluation of their suitability as die cavity inserts in the manufacture of high pressure diecasting (HPDC) dies. Apart from comparing the different LAM inserts with one another, their performance was also compared with components manufactured in a standard hot work steel. In the HPDC process, the die is unique to each component to be produced. Die cavities in particular are subjected to demanding conditions, such as cyclic heating caused by the introduction of molten aluminium at over $650^{\circ} \mathrm{C}$, followed by cooling in water-based die release medium at temperatures around $25^{\circ} \mathrm{C}$. Besides cyclic heating, the die cavities are also exposed to pressures exceeding $1500 \mathrm{MPa}$ during the injection of molten aluminium into the cavities. This application of LAM, therefore, poses extreme challenges to the technology. The results of this study confirmed that the metals used in some of the LAM technologies did indeed meet the demanding requirements of the current application, and can lead to significant time- and cost-saving during product or process developments. Based on these findings, a number of recommendations are made for users interested in the application of LAM to produce die cavities.
\end{abstract}

\section{OPSOMMING}

'n Aantal laser laagvervaardigingstegnologieë (LLV tegnolgieë) is in staat om volledig digte metaalkomponente te lewer, wat tot gevolg het dat hierdie tegnologie potensieel vir vormingsmatrys- of gietmatrysvervaardiging gebruik kan word (bekend as snelgereedskap). Drie van hierdie LLV tegnologieë is gekies vir evaluasie van hulle geskiktheid as gietvorminsetsels tydens die vervaardiging van gietmatryse vir hoë druk matrysgiet (HDMG). Benewens die onderlinge vergelyking van die verskillende LLV insetsels met mekaar, is hulle werkverrigting ook vergelyk met komponente wat in standaard warmwerkstaal vervaardig is. In die HDMG proses is die gietmatrys uniek aan elke komponent wat gevorm word. Die matrysholtes word veral aan uiterste toestande onderwerp, soos sikliese temperatuurverskille, veroorsaak deur die blootstelling aan gesmolte aluminium by meer as $650^{\circ} \mathrm{C}$, direk gevolg deur afkoeling in watergebaseerde smeermiddel by temperature van tipies $25^{\circ} \mathrm{C}$. Buiten sikliese verhitting, word die matrysholtes ook tydens die inspuit van gesmolte aluminium in die holtes blootgestel aan drukke hoër as $1500 \mathrm{MPa}$. Hierdie toepassing van LLV stel dus uiters hoë uitdagings aan die tegnologie. Die resultate van hierdie studie het bevestig dat die metale wat in sommige van die gekose LLV tegnologieë gebruik word, wel voldoen aan die besondere vereistes van die huidige toepassing, en dat die gebruik hiervan kan lei tot beduidende tyd- en kostebesparing tydens produk- of prosesontwikkeling. Gebaseer op hierdie bevindings word ' $n$ aantal aanbevelings gemaak vir gebruikers wat sou belangstel in die toepassing van LLV vir die vervaardiging van gietmatryse.

\footnotetext{
\# This article is an extended version of a paper presented at the 2011 RAPDASA conference.
} 


\section{INTRODUCTION}

Aluminium alloy components for a number of automotive applications are mass produced using a production process called high pressure die-casting (HPDC). This manufacturing process imposes severe stresses on the dies forming during processing. These stresses are caused when molten aluminium is injected at high pressure into the die cavities to fill them and then to solidify. Furthermore, the die manufacturing cost is a significant component determining the economic feasibility of the die-casting process. Dies are manufactured from steels - normally referred to as hot work steels - that can withstand the process conditions for an undetermined period of time. The terms die life and expected minimum die life before failure follow from the process-induced wear and tear. Dies must be able to produce components repetitively, with prescribed dimensions and good surface finish that comply with specification. After some use, die cavity wear and tear is noticeable to such an extent that the die becomes unusable, and a new die is required to meet the dimensional and surface requirements of the component being produced.

The most important die wear and tear failures are classified under two categories: washout and thermal fatigue. Washout damages are a direct result of the flow of the aluminium melt impinging on and rubbing against the die cavity surfaces. Corrosion is attributed to friction wear that is caused when the melt solidifies around the core surfaces, and when the casting is ejected. Thermal fatigue, the most influential failure mode in die-casting, reveals itself in two ways: heat checks and stress cracks. Thermal fatigue cracks occur as the die cavity surfaces are placed under tension when the cold $\left(25^{\circ} \mathrm{C}\right)$ water-based release agent impinges on the hot surfaces previously exposed to the aluminium melt. The cooling effect of the die lubricant spray on the underlying hot material causes a tensile stress in the hot die surface, causing surface cracks. This cycle is repeated each time a casting is made. The characteristic feature of heat checks is the appearance of fine cracking lines on surfaces that look like a spider's web. Stress cracks appear mainly in corners, and appear as individual and clearly defined cracks, sometimes filled with aluminium.

Because die manufacture is an expensive and time-consuming process, it is often the limiting factor in the drive towards reduced time-to-market for new product development. Should critical parts of a die or mould have to be redesigned and replaced, development costs could significantly increase, accompanied by undesirable time delays. For this reason, the cost saving and time reduction that could result from using additive manufacturing (AM) to produce complex parts of a die have become strong incentives for exploring the integration of $A M$ in the manufacturing chain, especially during product development. Applying this approach to the particularly challenging high temperature process of HPDC has formed the core of a research programme pursued by the authors in recent years. No similar attempts have been published to date.

In the research reported here, samples grown with the laser additive manufacturing (LAM) technology platforms LaserCUSING $\circledast$, EOS, and LENS were compared with each other under typical operational conditions. The aim was to assess the ability of the available AM metals to withstand the HPDC processing conditions. The AM cores were evaluated against standard hot work steel counterparts.

\section{LASER ADDITIVE MANUFACTURING TECHNOLOGIES INVESTIGATED}

In this research, two types of LAM technologies suitable for the manufacture of die components were investigated. One of the types uses the technology commonly referred to as powder bed layer deposition, with EOS and Concept Laser's LaserCUSING $®$ being the two selected leading technologies. Another approach to building a part from layers of material is to deliver powder by nozzles directly to the point where a focused laser melts the powder, fusing it into a part, line-by-line and layer-by-layer. Called powder deposition [2], the technique typically offers larger working envelopes, and the ability either to make parts or to repair existing parts. LENS, a leading technology in this field was selected for the 
current research. In this research, test coupons made with the materials given in Table 1 were evaluated.

Table 1: Metal powders used by service providers to manufacture test coupons

\begin{tabular}{|l|l|l|l|}
\hline Number & Manufacturer & System & Materials \\
\hline 1 & Concept Laser & M3 Linear & CL 50 WS (Hot work steel) \\
\hline 2 & Lens & Lens 750 Model & H13 (Din 1.2344 Hot work steel) \\
\hline 3 & EOS & EOSINTM250X & Direct Steel DS20 (steel) \\
\hline
\end{tabular}

\section{EXPERIMENTAL METHOD}

A test rig was designed and manufactured for the research. The rig is able to subject the LAM grown, and the standard steel manufactured specimens, to cyclic heating and cooling through immersion in liquid aluminium. The dipping cycle closely resembles the heating and cooling cycle of a typical aluminium die under casting conditions.

The suitability of any LAM technology that can produce fully dense metallic components acceptable for die-casting can be quickly assessed with the test rig. With economic feasibility in mind, and knowing that on standard hot work steel, evidence of heat checking damage appears after a few thousand cycles, 10,000 cycles was set as the experimental benchmark.

The assessment of damage inflicted on the cycled specimens was performed through optical microscopy of both faces and sharp corners, to analyse the extent of heat checking cracks, as well as the possible presence of corrosion pits. Furthermore, impact toughness and hardness values of cycled and un-cycled specimens were evaluated, in order to assess the extent of material property variation.

The initial experimental plan was for each LAM system supplier to fabricate four test coupons: three solids, and one with an open blind-hole passage. (Refer to the diagram in Figure 1.)

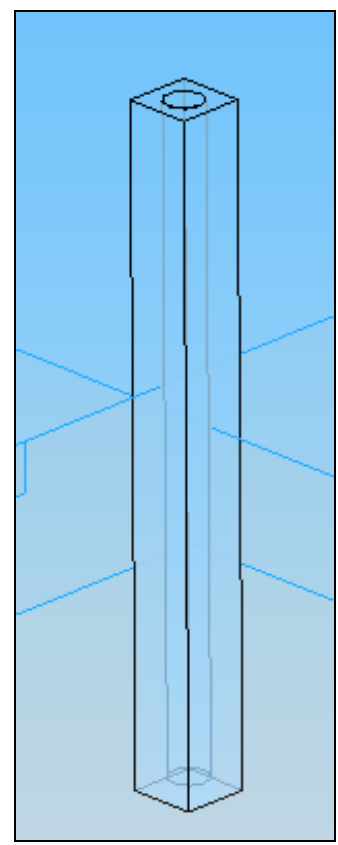

Figure 1: Test coupon with a square cross section of $10 \mathrm{~mm} \times 10 \mathrm{~mm}$, length $100 \mathrm{~mm}$, with blind hole diameter $6 \mathrm{~mm}$ up to $2 \mathrm{~mm}$ from the bottom 


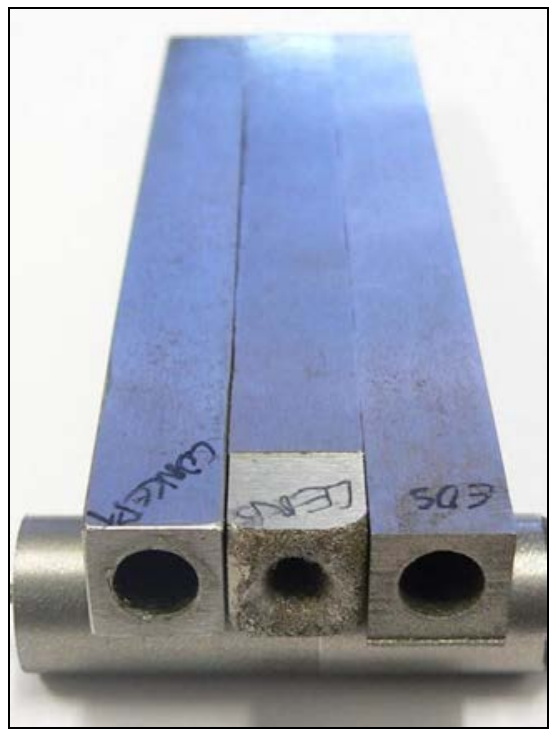

Figure 2: Test coupon hole aspect for the three systems

The results of initial visual and geometrical evaluation of the test coupons are shown in Table 2.

Table 2: Results of visual examination

\begin{tabular}{|l|l|l|l|}
\hline Description & $\mathbf{1}$ & $\mathbf{2}$ & $\mathbf{3}$ \\
\hline System & Concept M3 Linear & LENS 750 Model & EOS M 250 X \\
\hline Total shape & Complete & Complete & Complete \\
\hline Dimension change mm & \pm 0.1 & \pm 1.5 & \pm 0.1 \\
\hline Fine details & Very accurate & Poor & Very accurate \\
\hline Holes & $\begin{array}{l}\text { Sharp } \\
\text { Correct depth } \\
\text { Circular }\end{array}$ & $\begin{array}{l}\text { Deformed; required 1mm per side } \\
\text { machining }\end{array}$ & $\begin{array}{l}\text { Sharp } \\
\text { Correct depth } \\
\text { Circular }\end{array}$ \\
\hline Sharp edges & Sharp & Blunt & Sharp \\
\hline Sharp corners & Sharp & Blunt & Sharp \\
\hline $\begin{array}{l}\text { Surface roughness (finished } \\
\text { surfaces) }\end{array}$ & Smooth Rą 3.2 $\mu \mathrm{m}$ & Rough Rą 6.4 $\mu \mathrm{m}$ & Smooth Rą 3.2 $\mu \mathrm{m}$ \\
\hline & $\begin{array}{l}\text { Complete } \\
\text { coherence } \\
\text { Layer coherence } \\
\text { visible) }\end{array}$ & $\begin{array}{l}\text { Complete coherence } \\
\text { (Layers are not visible) }\end{array}$ & $\begin{array}{l}\text { Complete } \\
\text { coherence } \\
\text { (Layers are not } \\
\text { visible) }\end{array}$ \\
\hline Cracks [2] & No cracks & No cracks & Internal cracks \\
\hline Examination result & Very Good & Average & Good \\
\hline
\end{tabular}

The comparison of costs and finishing is shown in Table 3.

Table 3: Processing and finishing costs of test coupons

\begin{tabular}{|l|l|l|l|}
\hline Description & $\mathbf{1}$ & $\mathbf{2}$ & $\mathbf{3}^{(1)}$ \\
\hline System & Concept M3 Linear & LENS 750 Model & EOS M 250 X \\
\hline Layer thickness (mm) & 0.03 & 0.08 & 0.02 \\
\hline Total process time (hrs) & 3.5 & 2.5 & 10.5 \\
\hline Finishing time(hrs) & $\begin{array}{l}1+\text { (heat } \\
\text { treatment) }\end{array}$ & 4 & 1 \\
\hline Materials cost USD / kg [1] & 260 & 80 & 180 \\
\hline $\begin{array}{l}\text { Coupon benchmark cost vs wrought } \\
\text { manufactured }\end{array}$ & 5.2 & 1,7 & 2.2 \\
\hline Average cost & Very high & Medium & High \\
\hline
\end{tabular}




\subsection{Cyclic immersion in molten aluminium}

Figure 3 below shows the testing apparatus that was developed to simulate thermal cycling conditions that occur inside the cavity surfaces of the die when in contact with the aluminium melt. The specimens were mounted in this rig, with two in each arm end. At the same time, specimens mounted on both sides of the rotating arm were immersed either in aluminium at $630-700^{\circ} \mathrm{C}$ or in a cooling bath at $36-45^{\circ} \mathrm{C}$. Then the two opposite sides of the rotating arm were lifted and the immersion order was reversed. An average cycle time of 20 seconds was achieved. The heating and cooling cycle measured on the specimens ranged between 80 and $540^{\circ} \mathrm{C}$. A typical die-casting thermal shock cycle experiences ranges between 110 and $480^{\circ} \mathrm{C}$. This means that the specimens were subjected to an even more severe heat shock cycle than during normal casting conditions. The time of immersion in either aluminium melt or cooling medium was five seconds.

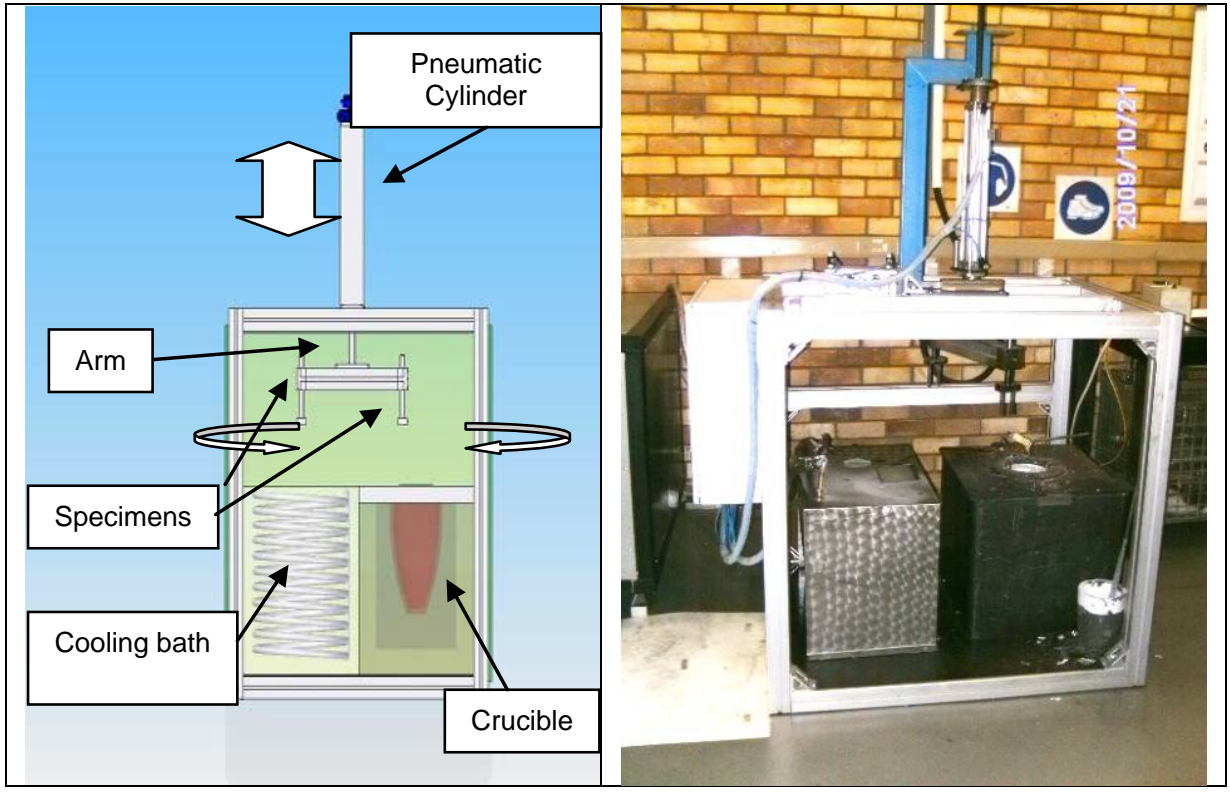

Figure 3: Aluminium melt cyclic dipping test rig

\section{EXPERIMENTAL RESULTS AND DISCUSSION}

The data and results obtained are described, discussed, and summarised in the following sections.

\subsection{Specimen preparation}

The LAM samples used in the experiment had a measured degree of average surface roughness of Rą of $3.2 \mu \mathrm{m}$. The preferred standard die cavity finish lies between Rą 0.80 and $0.20 \mu \mathrm{m}$. Surface grinding, a conventional material removal process, was used to bring the finish in line with the accepted norm. The grinding operation took care of both the roughness and the distortion induced by heat treatment of the LAM specimens. A maximum distortion of $0.2 \mathrm{~mm}$ was measured on the specimens.

The LAM samples measured between 9.98 and $10.10 \mathrm{~mm}$ on the requested $10.0 \times 10.0 \mathrm{~mm}$ cross section dimensions, after grinding to an acceptable finish free of distortion. The cross sections measured between 9.50 and $9.80 \mathrm{~mm}$. The measured deposition rate was $4 \mathrm{~cm}^{3} / \mathrm{h}$, which translates to $2.5 \mathrm{~h}$ for growing a specimen, and another half-an-hour for removal from the support plate. 
Table 4: Comparison of manufacturing times

\begin{tabular}{|l|l|l|l|l|l|l|l|}
\hline \multicolumn{2}{|c|}{$\begin{array}{c}\text { Specimen } \\
\text { HWS DIN 1.2344 }\end{array}$} & \multicolumn{2}{c|}{ Specimen EOS } & \multicolumn{2}{c|}{ Specimen Lens } & \multicolumn{2}{c|}{ Specimen Concept } \\
\hline Process & Time (h) & Process & Time (h) & Process & Time (h) & Process & Time (h) \\
\hline Milling & 2.5 & Laser sinter & 10.5 & Laser weld & 2.5 & Laser weld & 12 \\
\hline Grinding & 1 & Grinding & 1 & Grinding & 4 & Grinding & 1 \\
\hline Jig bore & & Jig bore & & Jig bore & & Jig bore & \\
\hline $\begin{array}{l}\text { Heat } \\
\text { treatment }\end{array}$ & 4 & $\begin{array}{l}\text { Heat } \\
\text { treatment }\end{array}$ & & $\begin{array}{l}\text { Heat } \\
\text { treatment }\end{array}$ & 4 & $\begin{array}{l}\text { Heat } \\
\text { treatment }\end{array}$ & 4 \\
\hline F grind & & F grind & & F grind & & F grind & \\
\hline Polish & & Polish & & Polish & & Polish & \\
\hline Fitting & & Fitting & & Fitting & & Fitting & \\
\hline Total & $\mathbf{7 . 5}$ & & $\mathbf{1 1 . 5}$ & & $\mathbf{1 0 . 5}$ & & $\mathbf{1 7}$ \\
\hline
\end{tabular}

(Note: Times are based on four specimens.)

\subsection{Heat checking and corrosion checks}

The results after cyclic immersion show that some aluminium welding occurred on cores grown with the LAM platforms, and to a lesser extent on the H13 core (Figure 4). Closer investigation showed evidence of cracks and pitting, mainly at the corners. The specimens were cleaned in a $\mathrm{NaCl}$ solution before conducting closer investigation.

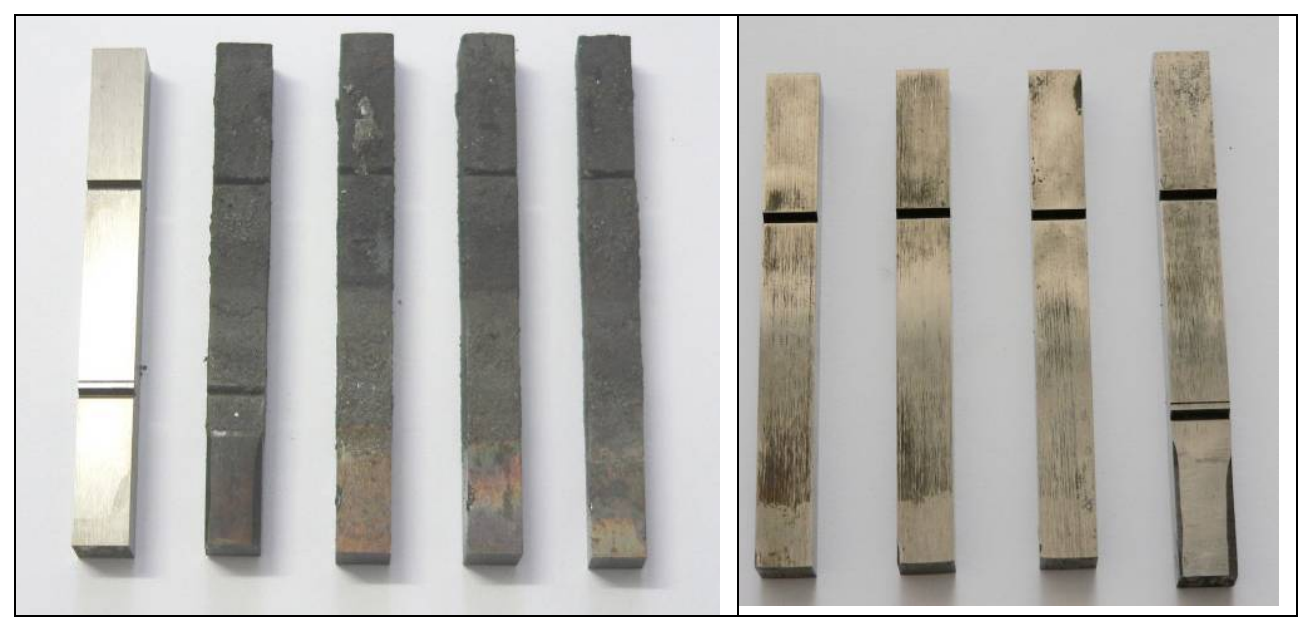

Figure 4: Specimens before and after 10,000 aluminium melt dipping cycles

Figure 5 shows these conditions at $5 x$ amplification of the cores.

\subsection{Mechanical integrity and microscopy}

The toughness and hardness of the specimens was determined before dipping and afterwards. A Vickers and Rockwell notch hardness testing machine was used to measure the hardness of the cores. Table 5 gives the results, using a $20 \mathrm{~kg}$ and $10 \mathrm{~kg}$ load. A clear softening effect was noticed on all specimens. It was less pronounced for the already soft EOS grown specimens. 


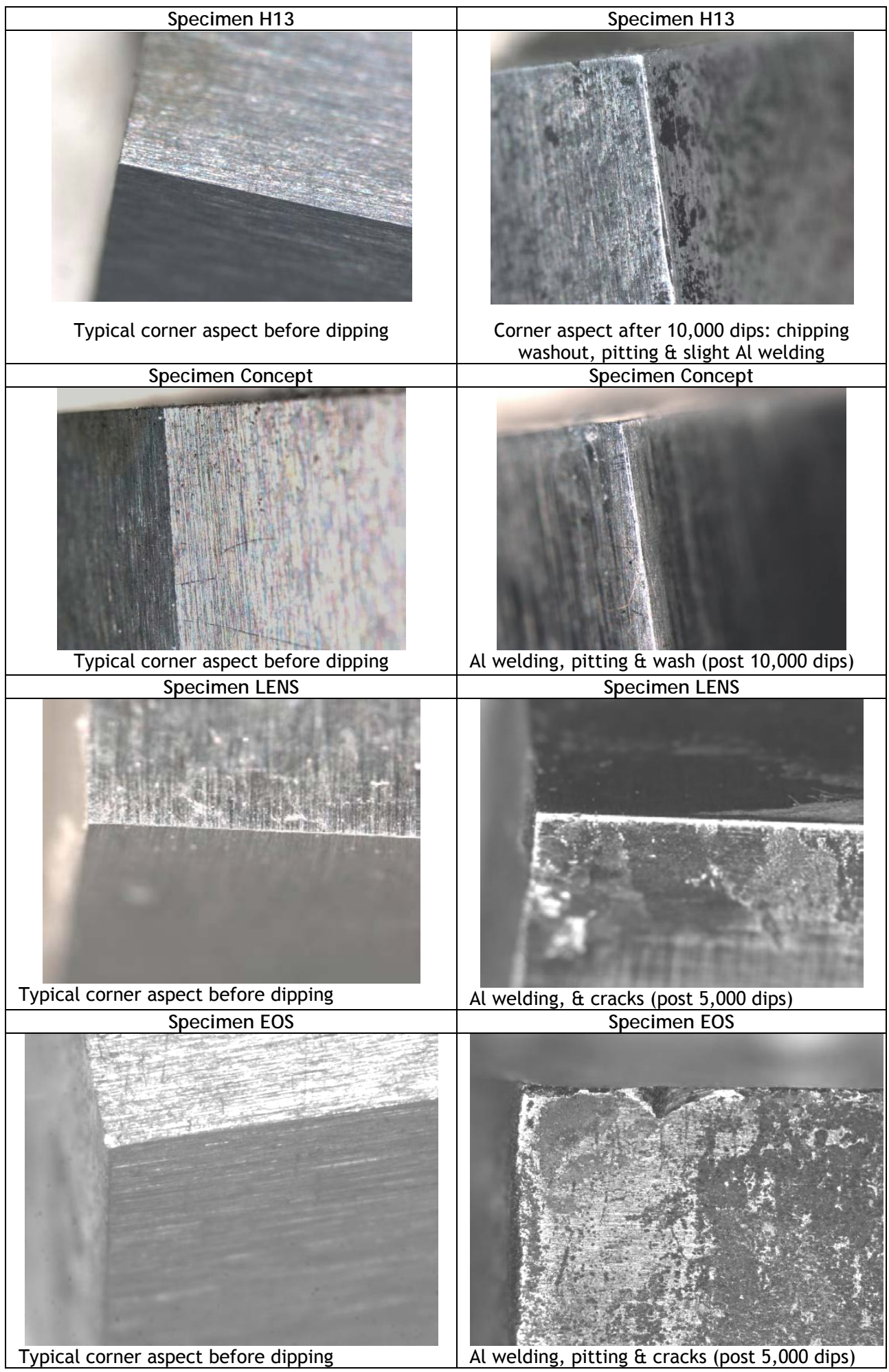

Figure 5: Optical micrographs of the specimen corners and notches at 5x magnification 
Table 5: Results of Vickers and Rockwell notch hardness tests

\begin{tabular}{|c|c|c|c|}
\hline $\begin{array}{c}\text { Core } \\
\text { H13 } \\
\text { Hardness (HRC) } \\
(20 \mathrm{~kg})\end{array}$ & $\begin{array}{c}\text { Core } \\
\text { LENS } \\
\text { Hardness (HRC) } \\
(20 \mathrm{~kg})\end{array}$ & $\begin{array}{c}\text { Core } \\
\text { EOS } \\
\text { Hardness (HV) } \\
(10 \mathrm{~kg})\end{array}$ & $\begin{array}{c}\text { Core } \\
\text { Concept } \\
\text { Hardness (HRC) } \\
(20 \mathrm{~kg})\end{array}$ \\
\hline Before: 47.4-54.6 & Before: $54-60.7$ & Before: $212.8-233.3$ & Before: 50.37-52.81 \\
\hline After: $40.6-48.7$ & After: 49.6-52.6 & After: $211.6-219.4$ & After: $33.0-35.67$ \\
\hline
\end{tabular}

Table 6 gives the changes in impact toughness found with the number of immersion cycles.

Table 6: Results of Charpy impact tests

\begin{tabular}{|c|c|c|c|}
\hline $\begin{array}{c}\text { Core } \\
\text { H13 (Din1.2344) } \\
\text { Impact energy (J oules) }\end{array}$ & $\begin{array}{c}\text { Core } \\
\text { LENS }\end{array}$ & $\begin{array}{c}\text { Core } \\
\text { EOS } \\
\text { Impact energy (J oules) }\end{array}$ & $\begin{array}{c}\text { Core } \\
\text { Concept } \\
\text { Impact energy } \\
\text { (J oules) }\end{array}$ \\
\hline Impact energy (J oules) & Not dipped 7.8 11.8 & Not dipped 7.8 & Not dipped 18.3 \\
\hline Dipped 8.8 & Dipped 8.8 & Dipped 7.8 & Dipped 8.0 \\
\hline
\end{tabular}

The $\mathrm{H} 13$ cores showed a decline in impact toughness - the result of the annealing effect experienced during the heat cyclic dipping test. Surprisingly, the LENS cores showed a slight increase in toughness, which can be attributed to a less brittle, more tempered core after experiencing the heat cycling treatment. The EOS cores showed no change in impact toughness. The Concept LaserCUSING ${ }^{\circledR}$ cores showed a steep decrease in toughness. This can be attributed to the fast annealing, accompanied by a loss of ductility or lower elongation properties of the cores, compared with their condition before cyclic dipping.

Metallographic investigation revealed some microstructure modification on the $\mathrm{H} 13$ and LaserCUSING $\otimes$ specimens. However, the $\mathrm{H} 13$ core showed slightly less crack growth than the LAM cores, which clearly revealed some degree of change. Only an extended dipping cycle experiment (20,000 dips) would reveal whether the difference in the size of cracks, and the crack density between the test coupons, is significant.

The partial loss of hardness of the $\mathrm{H} 13$ (Din 1.2344) test coupon (composition $\mathrm{C}=0.4 \%, \mathrm{Si}=$ $0 \%, \mathrm{Cr}=5.3 \%, \mathrm{Mo}=1.40 \%$, and $\mathrm{V}=1.0 \%$ with high red strength) when compared with the Concept CL 50 WS equivalent to Din 1.2709 powder (composition $\mathrm{C}=0.02 \%, \mathrm{Si}=0.1 \%, \mathrm{Mn}=$ $0.1 \%, \mathrm{Ni}=18.5 \%, \mathrm{Ti}=0.7 \%, \mathrm{Mo}=5.0 \%$ and $\mathrm{Co}=8.8 \%$ ) was surprising. The greater loss of hardness can be attributed to the high $\mathrm{Ni}$ (above 18\%) content of the Concept alloy. $\mathrm{Ni}$ content in alloy steels normally lowers the martensite to austenite transformation temperature (which tends to be lower than the Al melt temperature), resulting in rapid softening of the steel. The slower softening rate of the conventional ( $\mathrm{H} 13)$ and LENS Din 1.2344 specimens clearly indicates that the heat treatments were done in a non-protective atmosphere.

Further metallographic investigation did not reveal significant microstructure changes in the Concept, LENS, and H13 specimens. However, the EOS specimen clearly showed some degree of change. The micrographs of the microscopic analysis of the EOS specimens in Figure 6 indicate an increased presence of gas pores, accompanied by crack formation. 


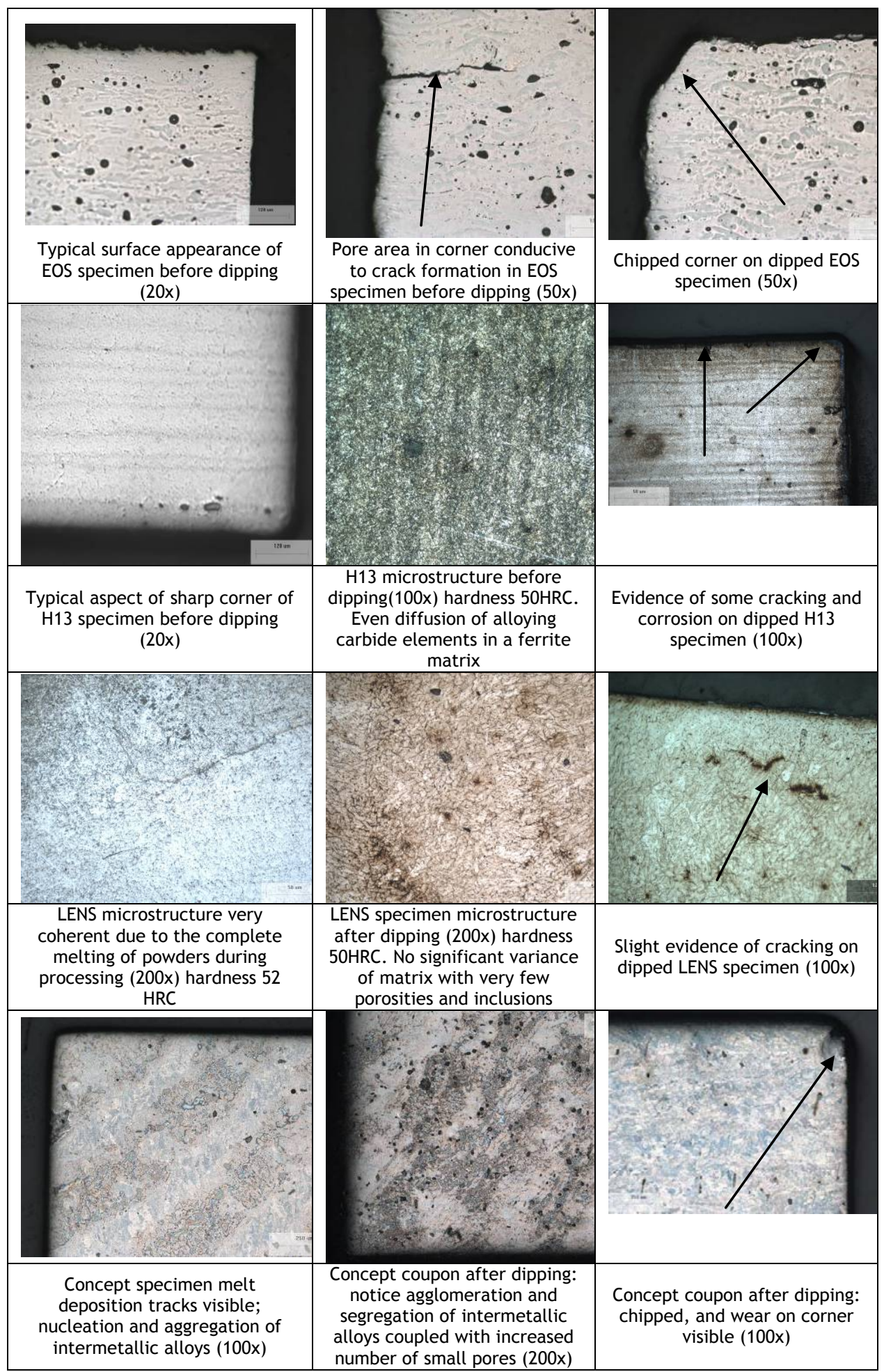

Figure 6: Optical micrographs of H13, LENS, Concept Laser, and EOS samples 


\subsection{Discussion and recommendations}

Previous findings on EOS grown cores $[3,4]$ showed that this technology was adequate to produce:

- good candidates for time compression of product development or production of prototype production runs;

- $\quad$ cores that will withstand industrial-standard HPDC processing conditions to produce small batches - i.e. $<5,000$ shots. Larger batches could be produced if it was economically feasible to prepare spare cores for replacement after a predetermined number of shots;

- good near-net capability that can reproduce geometry with an allowed material tolerance of $0.25 \mathrm{~mm}$, but at slow rate of deposition (typically $2-10 \mathrm{~cm}^{3} /$ hour);

- $\quad$ significantly reduced time to manufacture dies if due consideration is given to size and volume constraints of the LAM platform.

From the current investigation, cores grown with Direct Steel 20 have shown low core and surface hardness, as well some degree of porosity. Low core hardness and porosity limit extensive use under molten aluminium processing conditions. Fast crack propagation, resulting in surface degradation, is the main limiting factor. It was interesting to note that the degree of porosity evident in the LAM grown cores revealed some positive results under processing conditions. When such a core is exposed to heat, the air present in the pores expands and creates a film that allows for a longer melt flow distance and a faster solidification cooling rate.

The performance of the LENS LAM grown cores [5] under these particular experimental conditions was remarkable:

- They showed an ability to withstand industrial-standard HPDC processing conditions, to produce castings equivalent to standard die materials.

- The time to manufacture dies can be significantly reduced due to the availability of machines with a build envelope size equivalent to NC die machining capability (motion $150 \mathrm{~cm} \times 90 \mathrm{~cm} \times 90 \mathrm{~cm}$ (z-axis)). The LENS multi-nozzle capability opens opportunities for further development of:

o Strategies of fast rates generally, and lower rates of material deposition where geometrical accuracy is required.

o Multi-material deposition.

o Full die manufacture and die repair, due to the availability of platforms with multi-axis range of motion (up to seven).

The 3D model generation of cores before laser growing for the LENS system should include an overall surface material allowance of between 1.5 and $2.5 \mathrm{~mm}$.

The current work gives clear evidence that specimens manufactured from powders equivalent to hot work steel DIN 1.2344 have core and surface hardness equivalent to the standard die material. The loss of hardness experienced under cyclic heat testing is significantly less than that experienced with the standard hot work steel counterparts used by industry. This finding is supported by microscopy, which reveals finer and welldistributed metal phases and constituent alloy element diffusion in the steel matrix when compared with the industry counterpart.

The performance of the LaserCUSING ${ }^{\circledR}$ LAM grown components [6] can be considered quite remarkable:

- They are able to produce die components for standard industrial production batches.

- Their good near-net capability is able to reproduce geometry with an allowed material tolerance of $0.3 \mathrm{~mm}$.

- A reasonable turnaround time, ideal for complex geometry cavity inserts requiring integrated cooling that is particularly difficult or impossible to attain with normal mechanical metal removal techniques. 
- $\quad$ Availability of steel powders with similar characteristics to standard used hot work steels, e.g. Din 1.2709.

As far as core and surface hardness properties are concerned, the current research yielded results that compare very favourably with the standard counterpart. The basic metal quality was found to be better than the industry standard hot work steel.

From these and previously-published research results, it is clear that the following aspects have to be considered in respect of the use of laser additive manufacturing to produce die or mould components:

- Component geometry is very complex - i.e. in order to manufacture conventionally, multiple material removal technologies would be required, such as electric discharge machining (EDM), milling, and grinding.

- Hot work steel can be deposited through LAM with acceptable quality.

- Cost must be competitive. A rule of thumb is to look at the amount of material that needs to be removed from a billet or piece of wrought material to manufacture a die cavity. If the amount of material removed is above $75 \%$, there is a good likelihood that the component is a candidate for LAM.

As a final recommendation based on the overall outcome of the research, a number of die manufacturing strategies should be applied. To minimise deposition and die manufacture time, consider:

- $\quad$ growing the core over a compatible material substrate;

- $\quad$ in the design of cores or die structures fixtures, allowing for the required holding and setting up when finishing parts by conventional machining methodologies;

- designing hollow cores, with the opportunity to include cooling in the components;

- planning for components to be grown at the required final hardness, free of distortion.

\section{CONCLUSION}

The accelerated testing of cores manufactured through the EOS-DMLS, Concept Laser's LaserCUSING ${ }^{\circledR}$, and the LENS blown powder LAM technology under typical production conditions provided valuable insight into the applicability of these technologies.

Comparative analyses of both the LaserCUSING $®$ and the LENS specimens with the standard die steel showed that both would be able to fulfil this role in very similar ways.

The near-net shape manufacturing capability of powder bed LAM technology makes systems such as EOS the choice for developmental, prototype, or short production run dies.

Concept Laser's LaserCUSING technology is a good choice for complex, small-to-medium die inserts that must be able to withstand standard aluminium production rates.

The LENS blown powder LAM process is the choice for the manufacture of larger dies and the repair of production dies. More extensive mechanical removal type of finishing operations will be required when compared with the powder bed technology LAM platforms.

LAM technology has matured enough for its widespread use by industry. Economic feasibility will be the key to a more rapid adoption of the technology by industry. The range of applications could multiply exponentially if the gap is reduced between the cost of a LAM technology using steel powders, versus wrought steels and allied mechanical removal technologies. 


\section{REFERENCES}

[1] Abdel Ghany, K. 2006. Benchmark comparison to evaluate five 3D printers and rapid prototyping systems, $7^{\text {th }}$ Annual RAPDASA International Conference, Cape Town, South Africa.

[2] Wohlers, T. 2003. Rapid prototyping, tooling \& manufacturing state of the industry, Annual Worldwide Progress Report, Wohlers Association Inc, USA.

[3] Pereira, M.F.V.T., Williams, M. \& Bruwer, R. 2009. Rapid die manufacturing using direct laser metal deposition, J ournal for New Generation Sciences, 7(3), 58-69.

[4] Pereira, M.F.V.T., Williams, M. \& du Preez, W.B. 2008. Characterization of metal powder based rapid prototyping components under aluminium high pressure die casting process conditions, $9^{\text {th }}$ Annual RAPDASA International Conference, Bloemfontein, South Africa.

[5] Pereira, M.F.V.T., Williams, M. \& du Preez, W.B. 2010. Characterization of metal powder based rapid prototyping components with respect to aluminium high pressure die casting process conditions, J ournal for New Generation Sciences, 8(2), 85-94.

[6] Pereira, M.F.V.T., Kunene, G., Spiering, A. \& du Preez, W.B. 2009. Performance of LaserCUSING $\otimes$ metal powder specimens under aluminium high pressure die-casting process conditions, $10^{\text {th }}$ Annual RAPDASA International Conference, East London, South Africa. 
http://sajie.journals.ac.za 